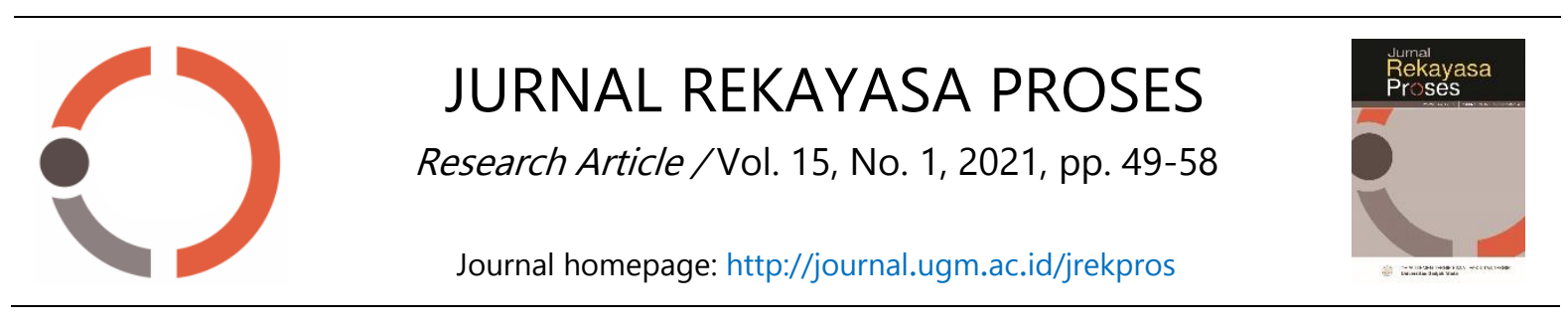

\title{
Kinetics Study of Paracetamol Production from Para- Aminophenol and Acetic Anhydride
}

\author{
Rifki Wahyu Kurnianto ${ }^{1 *}$, Mohammad Fahrurrozi ${ }^{1}$, Hilda Ismail ${ }^{2}$, Raden Rara Endang \\ Lukitaningsih ${ }^{2}$, Indah Tri Nur'aini ${ }^{1}$, Pudjono ${ }^{2,3}$, Rochmadi ${ }^{1}$, Ari Sudarmanto ${ }^{2}$, and Ratna Asmah \\ Susidarti \\ ${ }^{1}$ Department of Chemical Engineering, Faculty of Engineering, Universitas Gadjah Mada, J \\ Grafika No. 2 Kampus UGM, 55281 Yogyakarta \\ ${ }^{2}$ Faculty of Pharmacy, Universitas Gadjah Mada, J Sekip Utara Kampus UGM, 55281 \\ Yogyakarta \\ ${ }^{3}$ Faculty of Science and Technology, Universitas Peradaban, Jl Raya Pagojegan Km 3, \\ Paguyangan, Brebes, Jawa Tengah \\ * Corresponding author: rifki.wahyu.k@ugm.ac.id
}

(Submission: 7 March 2021; Revision: 19 April 2021; Acceptance: 23 April 2021)

\section{A B S T R A C T}

In the last decade, Indonesia intensifies the efforts to reduce pharmaceutical imports. One of the initiatives is establishing a paracetamol production facility to start operating in 2024 . Kinetics study is needed as a basis to design the paracetamol reactor. This study investigated the optimal temperature, reactant mole ratio, and agitation speed in the reactor for paracetamol production. In this study, aqueous solution of para-aminophenol was reacted with acetic anhydride. The mole ratio of para-aminophenol to acetic anhydride was varied to $1: 1$, $1: 1.2,1: 1.5$, and $1: 2$ while the temperature was varied to $80^{\circ} \mathrm{C}, 90^{\circ} \mathrm{C}$, and $110^{\circ} \mathrm{C}$. However, due to uncontrolled heat of the reaction and limitation of the mixture's boiling point, the actual reaction temperatures were $86^{\circ} \mathrm{C}, 90^{\circ} \mathrm{C}$, and $108^{\circ} \mathrm{C}$. In addition, the agitation speed of 250 RPM and 350 RPM were also studied. Thin layer chromatography (TLC) and densitometry were used to determine the concentration of paracetamol in the reacting mixture. The optimum temperature, reactant mole ratio, and agitation speed in this study were $108^{\circ} \mathrm{C}, 1: 1.5$, and 350 RPM, respectively. In addition, a reaction performed under those operating parameters gave the reaction rate constant of $1.95 \mathrm{~L} \mathrm{~mol}^{-1} \mathrm{~min}^{-1}$.

Keywords: acetic anhydride; kinetics; para-aminophenol; paracetamol; pharmaceutical industry

\section{ABSTRAK}

Dalam sepuluh tahun terakhir ini, Indonesia bertekad mengurangi impor bahan baku farmasi. Salah satu upaya yang dilakukan adalah membangun fasilitas produksi parasetamol yang akan mulai beroperasi pada tahun 2024. Studi kinetika diperlukan sebagai dasar perancangan 
reaktor parasetamol. Oleh karena itu, penelitian ini mengkaji kondisi operasi optimal pada reaksi produksi parasetamol yang akan dibutuhkan sebagai dasar perancangan pabrik. Pada percobaan ini, para-aminofenol direaksikan dengan anhidrida asetat dengan media air. Rasio mol para-aminofenol terhadap asetat anhidrida divariasikan 1:1 1:1,2, 1:1,5, dan 1:2 sedangkan temperatur divariasikan $80^{\circ} \mathrm{C}, 90^{\circ} \mathrm{C}$, dan $110^{\circ} \mathrm{C}$. Akan tetapi, karena panas reaksi yang tidak dikontrol dan batasan berupa titik didih dari campuran reaksi, temperatur aktual reaksi menjadi $86^{\circ} \mathrm{C}, 90^{\circ} \mathrm{C}$, dan $108{ }^{\circ} \mathrm{C}$. Selain itu, kecepatan putaran pengadukan juga divariasikan pada angka 250 RPM dan 350 RPM. Kromatografi lapis tipis (KLT) dan densitometri digunakan untuk menentukan konsentrasi parasetamol dalam campuran reaksi. Temperatur, rasio mol reaktan, dan kecepatan putaran pengadukan yang optimum pada penelitian ini masing-masing adalah $110^{\circ} \mathrm{C}, 1: 1,5$, dan 350 RPM. Selain itu, reaksi yang dilakukan dengan kondisi operasi tersebut menghasilkan konstanta laju reaksi 1,95 $\mathrm{L} \mathrm{mol}^{1}$ menit $^{-1}$.

Kata kunci: anhidrida asetat, industri farmasi, kinetika, para-aminofenol, parasetamol

\section{Introduction}

Currently, Indonesia is reported to import $90 \%$ of pharmaceutical materials. As the fourth most populated country in the world with the population of 271 million people in 2019 (UNDESA, 2019), Indonesia imported 6,471 tons of paracetamol in 2016 and it was increased to 7,014 tons in 2019 (BPS-Statistics Indonesia, 2016; BPS-Statistics Indonesia, 2019). A private company, PT Riasima Abadi Farma, had tried to produce paracetamol some time ago. However, PT Riasima Abadi Farma could only produce 150 tons per year of paracetamol due to the high production cost. This situation highlights the difficulty for a private company to survive in the pharmaceutical business. To improve the nation's self-sufficiency in pharmaceutical industry, Indonesia government has taken strategic initiatives. One of the government's plans is to build state-owned paracetamol production plant in 2024 (Ministry of Research and Technology of the Republic of Indonesia, 2020).

Paracetamol, also known as acetaminophen, is commonly used as analgesic and antipyretic drug (Mane et al.,
2018; Sawalha, 2018) and is produced more than 100,000 tons per year universally (Joncour et al., 2014). Apart of being used directly, some scientists tried to improve paracetamol by modifying the molecules. Van de Straat et al. (1987) concluded that 3,5dialkyl substitution resulted in lower chance of inducing hepatotoxicity. It was also found that substituting acetic acid to the molecule can significantly enhance the antipyretic and analgesic effect (Kumar et al., 2013).

Paracetamol can be synthesized from different starting compounds. For instances, some scientists synthesized paracetamol from nitrobenzene by means of catalytic hydrogenation in the presence of acid (Jing, 2014; Min et al., 2008; Rode et al., 1999, 2002); some used $p$-nitrophenol as starting material (Abdullaev et al., 2014; Du et al., 2004); and some others studied the reaction pathway from hydroquinone (Bhattacharya et al., 2006; Joncour et al., 2014; Mane et al., 2018). Although the starting materials were different, many pathways led to the reaction of para-aminophenol acetylation with the addition of acetic anhydride to produce paracetamol. Hence, the operational 
conditions of this reaction are crucial to be optimized regardless of the pathway used.

The reaction of para-aminophenol acetylation to acetaminophen shown in Equation (1) has been studied by many scientists. Caldeira (2010) tried to add phosphoric acid to catalyze the reaction, in his study; Jiang and $\mathrm{Ni}$ (2018) investigated the effect of water content and different temperature up to $80{ }^{\circ} \mathrm{C}$ to the reaction; and Ralph et al. (2019) reacted para-aminophenol with acetic anhydride in water with a certain molar ratio for 10 minutes and added sodium hydrosulfite to increase purity. However, this reaction was influenced by many parameters such as mole ratio of the reactants, mixing, and the temperature (Jiang and $\mathrm{Ni}, 2018$ ) and it was consistent with our preliminary study.

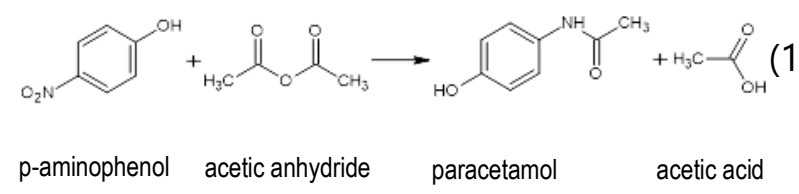

To our knowledge, the effect of temperature reaction above $80^{\circ} \mathrm{C}$ is scarcely reported as Jiang and $\mathrm{Ni}$ (2018) only studied the kinetics of the reaction with the temperature up to $80^{\circ} \mathrm{C}$ and the trend of the kinetic rate constant up to $80{ }^{\circ} \mathrm{C}$ had not shown any sign of decreasing yet. Jie et al. (2003) and Ralph et al. (2019) already synthesized paracetamol from paraaminophenol with the reaction temperature up to $150{ }^{\circ} \mathrm{C}$, but they did not include the kinetics analysis. Moreover, study about the effect of agitation speed on this reaction still cannot be easily found. For examples, Jiang and $\mathrm{Ni}$ (2018) set the agitation speed to one value of 200 RPM while Lee et al. (2013) performed the reaction at 250 RPM and Mane et al. used the RPM of 300 .
Additionally, we also varied the mole ratio between para-aminophenol and acetic anhydride as studies about this are hardly found. Amin and Iqbal (2015) used the mole ratio of 1:11 in their study; Caldeira (2010) excessed the acetic anhydride by 1.5 times of the moles of para-aminophenol; while Jiang and $\mathrm{Ni}$ (2018) went far beyond that with the mole ratio of 1:13.8 (para-aminophenol:acetic anhydride).

Hence, the objective of this study was to learn the optimum operational condition for the future paracetamol production plant by investigating the effect of temperature, agitation speed, and reactant mole ratio to the conversion of para-aminophenol. Furthermore, the experimental data were fitted to a second order reaction rate equation to determine the kinetic rate constant. The rate constants will also be used to calculate the optimum reaction time for the base of reactor size calculation. The novelty of this study lies in the kinetics analysis of the reaction on higher temperature and the study of the effect of the reactants' mole ratio and the agitation speed on the kinetics constants.

\section{Research Methodology}

\subsection{Materials}

The reactants consisted of paraaminophenol (Sigma Aldrich UK Ltd., $\geq 99 \%$ ) and acetic anhydride (TEDIA, $\geq 97 \%$; chloride max 5 ppm; heavy metal max 2 ppm; iron max 5 ppm; phosphate max $0.001 \%$; residue after evaporation $\max 0.003 \%$; sulphate $\max 5$ ppm). Demineralized water was used as the solvent in the reaction. A mixture of acetone (MALLINCKRODT, $\geq$ 99.5\%), ammonia solution (Merck, 25\%), and chloroform (Merck, $\geq 99.5 \%$ ) were used as the mobile 
phases for thin-layer chromatography (TLC) analysis.

\subsection{Procedures}

To produce paracetamol, firstly, 21.8 grams para-aminophenol (PAF) was dissolved in 60 $\mathrm{ml}$ of demineralized water in a three-neck round bottom flask (Figure 1) operated as a batch reactor. The mixture was heated to the certain reaction temperature. Acetic anhydride (AA) with certain mole ratio with respect to para-aminophenol was added to the solution and the reaction was carried out with certain rotations per minute (RPM) stirring for 30 minutes.

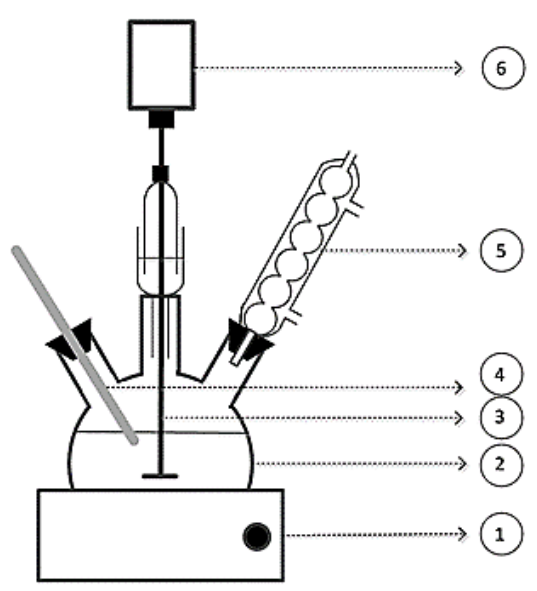

Figure 1. Batch reactor for paracetamol kinetics study

Samples were taken every 5 minutes and analyzed using thin layer chromatography. A combination of acetone:chloroform:ammonia $(25 \%-v / v)$ with the volume ratio of 8:2:0.1 was used as mobile phase in the TLC analysis. The paracetamol concentration was determined by analyzing the TLC plate using densitometry (Pyka et al., 2011). The concentrations of paraaminophenol and acetic anhydride were calculated stoichiometrically from paracetamol concentration data by assuming that para-aminophenol was the limiting reactant.
In this experiment, the effect of the variations in reactant mole ratios, temperatures, and agitation speeds were investigated. To achieve those objectives, the mole ratio of para-aminophenol to acetic anhydride was varied to $1: 1,1: 1.2,1: 1.5$, and $1: 2$ while the temperature was varied to 80 , 90, and $110{ }^{\circ} \mathrm{C}$. In addition, the agitation speed of 250 RPM and 350 RPM were tested. Table 1 shows the summary of the operating conditions of each run in this experiment.

Table 1. Summary of the experiment

\begin{tabular}{cccc}
\hline $\begin{array}{c}\text { Run } \\
\left({ }^{\circ} \mathrm{C}\right)\end{array}$ & $\begin{array}{c}\text { Temperature } \\
\text { Mole Ratio } \\
\text { (PAF:AA) }\end{array}$ & $\begin{array}{c}\text { Stirring Rotation } \\
\text { Speed (RPM) }\end{array}$ \\
\hline \multicolumn{4}{c}{ The study of temperature effect to the reaction } \\
\hline 1 & 80 & $1: 1$ & 250 \\
2 & 90 & $1: 1$ & 250 \\
3 & 110 & $1: 1$ & 250 \\
\hline \multicolumn{4}{c}{ The study of mole ratio effect to the reaction } \\
\hline 4 & 80 & $1: 1$ & 250 \\
5 & 80 & $1: 1.2$ & 250 \\
6 & 80 & $1: 1.5$ & 250 \\
7 & 80 & $1: 2$ & 250 \\
\hline The study of agitation speed effect to the reaction \\
\hline 8 & 90 & $1: 1$ & 250 \\
9 & 90 & $1: 1$ & 350 \\
\hline Optimum operating condition from previous studies \\
\hline 10 & 110 & $1: 1.5$ & 350 \\
\hline \multicolumn{5}{c}{} \\
\hline
\end{tabular}

Para-aminophenol and acetic anhydride concentrations were calculated stoichiometrically from concentration of paracetamol, and the results were fitted to a second order reaction equation with PAF as the limiting reactant as shown in Equation (2) to calculate the rate of reaction constant $(K)$.

$$
r_{P C T}=-\frac{d C_{P A F}}{d t}=k \cdot C_{P A F} \cdot C_{A A}
$$

Furthermore, activation energy $\left(E_{a}\right)$ and frequency factor $(A)$ are calculated using linear regression from Equation (3).

$$
\ln k=\frac{-E_{a}}{R} \frac{1}{T}+\ln A
$$




\section{Results and Discussion}

\subsection{Effect of Temperature}

In this experiment, the temperature effect on the conversion of para-aminophenol (PAF) was investigated by varying the temperature with the designed value of 80,90 , and $110^{\circ} \mathrm{C}$. However, due to the heat of the reaction, the actual lower temperature value was increased to $86^{\circ} \mathrm{C}$ instead of $80^{\circ} \mathrm{C}$. Meanwhile, because the mixture boiled at $108^{\circ} \mathrm{C}$, the actual upper temperature value was $108^{\circ} \mathrm{C}$ instead of 110 ${ }^{\circ} \mathrm{C}$. Therefore, the actual temperatures of the reaction in this study were 86,90 , and $108^{\circ} \mathrm{C}$. Figure 2 shows an example of TLCdensitometry chromatogram produced from the run with the temperature of $86^{\circ} \mathrm{C}$.

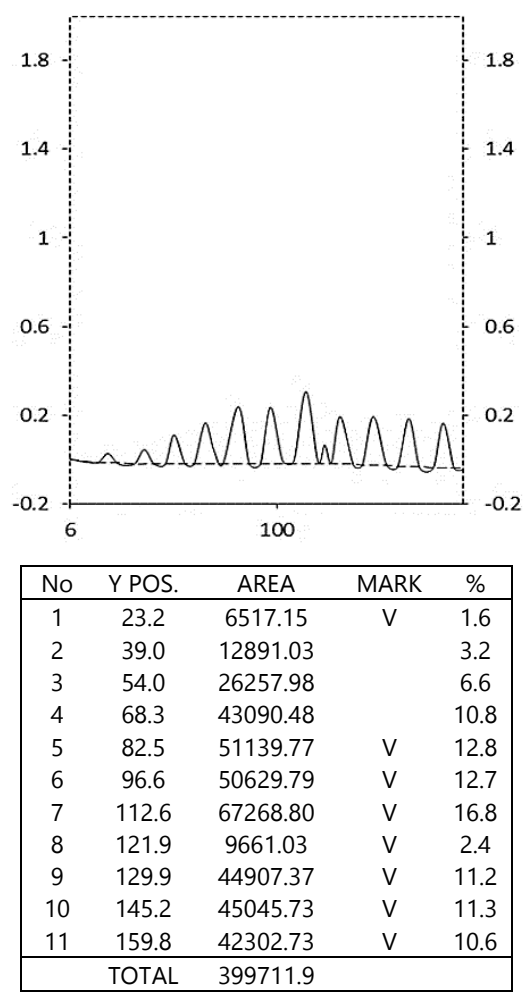

Figure 2. TLC-densitometry chromatogram for the run with temperature of $86^{\circ} \mathrm{C}$

The data obtained from the chromatograms were calculated to obtain the conversion of PAF in different temperature which were shown in Figure 3 along with the data fitting results of Eq. (2) for every temperature.

As shown in Figure 3, the temperature of $108{ }^{\circ} \mathrm{C}$ produced the fastest reaction among the three temperatures that were studied in this experiment. At the temperature of $108^{\circ} \mathrm{C}$, the conversion of the reaction already reached $100 \%$ in the five minutes of the reaction while at the lower temperatures, the reaction reached the maximum conversion only after 25 minutes. Table 2 summarizes the reaction rate constants at various temperature. The activation energy $\left(E_{a}\right)$ and the frequency factor $(A)$ of this reaction was calculated using Eq. (3) and the values were found to be $143,857.14 \mathrm{~J} / \mathrm{mol}$ and $7.7 \times 10^{9}$ L. $\mathrm{mol}^{-1} \cdot \mathrm{min}^{-1}$ respectively.

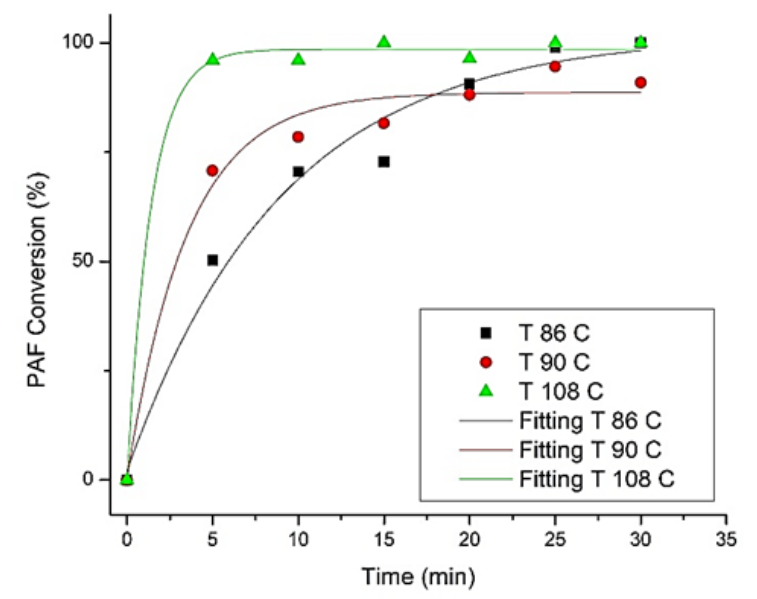

Figure 3. Conversion of PAF in different reaction temperature (reactant mole ratio of $1: 1$; agitation speed of $250 \mathrm{rpm}$ )

This result was in accordance with the experiment done by Jiang and $\mathrm{Ni}$ (2018) which resulted in increasing rate constant along with the increase of temperature in the range of $50-80{ }^{\circ} \mathrm{C}$ ranging from 0.436 L.mol ${ }^{-1} \cdot \mathrm{min}^{-1}$ to $1.421 \mathrm{~L} \cdot \mathrm{mol}^{-1} \cdot \mathrm{min}^{-1}$. However, even at the highest temperature investigated in this experiment $\left(108{ }^{\circ} \mathrm{C}\right)$, the reaction rate constant value was still lower than the one at 
the temperature of $80^{\circ} \mathrm{C}$ in Jiang and $\mathrm{Ni}^{\prime} \mathrm{s}$ experiment. The lower value of reaction rate constant in this experiment was possibly due to other unoptimized operating parameter, such as water content. Jiang and Ni (2018) concluded that the weight ratio between acetic acid and water of 7:3 produced the solubility for the reaction while in this study, we used a weight ratio of 1:1.85.

Table 2. Reaction rate constant $(K)$ at various temperature

\begin{tabular}{ccc}
\hline $\begin{array}{c}\text { Temperature, } \\
T\left({ }^{\circ} \mathrm{C}\right)\end{array}$ & $\begin{array}{c}\text { Reaction rate } \\
\text { constant, } k \\
\left(\text { L.mol }^{-1} . \mathrm{min}^{-1}\right)\end{array}$ & $\begin{array}{c}\text { Correlation } \\
\text { coefficient, } R^{2}\end{array}$ \\
\hline 86 & 0.080 & 0.843 \\
90 & 0.177 & 0.704 \\
108 & 1.414 & 0.675 \\
\hline
\end{tabular}

\subsection{Effect of Reactant Mole Ratio}

In addition to the temperature variation, reactant mole ratio effect on the conversion was also investigated in this study. The paraaminophenol to acetic anhydride mole ratio was varied by $1: 1,1: 1.2,1: 1.5$, and 1:2. The experiment was done at the temperature of $86{ }^{\circ} \mathrm{C}$ with the agitation speed of 250 RPM. The conversion of para-aminophenol was calculated with the same method as previously mentioned in the earlier section and the results were shown in Figure 4.

Figure 4 shows that in just 5 minutes, the PAF to AA mole ratio of $1: 1.2$ and $1: 1.5$ had almost reached $100 \%$ conversion. Meanwhile, for the first 15 minutes, the PAF conversion rate with mole ratio of $1: 1$ was the slowest whereas the mole ratio of $1: 2$ was just a little higher than that. Even after 30 minutes, the mole ratio of $1: 2$ could not reach $100 \%$ conversion while the other mole ratios were already completed the $100 \%$ conversion. Table 3 recapitulates the reaction rate constant calculated from the data with various $P A F$ to $A A$ mole ratios.

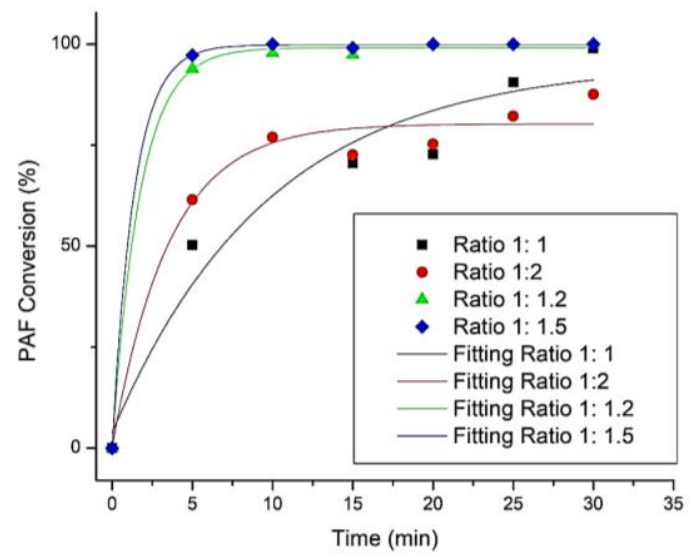

Figure 4. Conversion of PAF with different PAF to AA mole ratio (temperature of $86{ }^{\circ} \mathrm{C}$; agitation speed of $250 \mathrm{rpm}$ )

Table 3. Reaction rate constant $(K)$ in various reactant mole ratio

\begin{tabular}{ccc}
\hline $\begin{array}{c}\text { Mole ratio } \\
\text { (PAF:AA) }\end{array}$ & $\begin{array}{c}\text { Reaction rate } \\
\text { constant, } k \\
\left(\text { L. } \mathrm{mol}^{-1} . \mathrm{min}^{-1}\right)\end{array}$ & $\begin{array}{c}\text { Correlation } \\
\text { coefficient, } R^{2}\end{array}$ \\
\hline $1: 1$ & 0.080 & 0.843 \\
$1: 1.2$ & 0.220 & 0.820 \\
$1: 1.5$ & 0.955 & 0.758 \\
$1: 2$ & 0.066 & 0.750 \\
\hline
\end{tabular}

Table 3 shows that the reaction rate constant was increasing as the PAF to AA mole ratio was increased from 1:1 to 1:5. However, the reaction rate constant decreased when the mole ratio was further increased to 1:2. This exception might be due to the presence of side reaction between acetaminophen and excess acetic anhydride to form 4'-acetoxyacetanilide (Jiang and $\mathrm{Ni}$, 2018). Therefore, both Figure 2 and Table 3 show that the optimum PAF to AA mole ratio in this experiment was 1:1.5.

\subsection{Effect of Agitation speed}

The third parameter that was studied in this experiment was agitation speed. The success of PAF and $A A$ reaction relies on 
perfect dissolution of PAF in the reaction mixture and hence, agitation speed is crucial to enhance the dissolution rate. In this experiment, the agitation speed of 250 RPM was compared with the agitation speed of 350 RPM. The experiment was done at the temperature of $90{ }^{\circ} \mathrm{C}$ with PAF to AA mole ratio of $1: 1$. The conversion of $P A F$ in this experiment is presented in Figure 5 and the reaction rate constant is summarized in Table 4. It was shown in both Figure 5 and Table 4 that the agitation speed of 350 RPM produced higher reaction rate than the agitation speed of 250 RPM by reaching $100 \%$ conversion faster and producing higher reaction rate constant.

Table 4. Reaction rate constant $(k)$ in different agitation speed

\begin{tabular}{ccc}
\hline $\begin{array}{c}\text { Agitation } \\
\text { speed } \\
(\mathrm{RPM})\end{array}$ & $\begin{array}{c}\text { Reaction rate } \\
\text { constant, } k\left(\mathrm{~L} \cdot \mathrm{mol}^{-}\right.\end{array}$ & $\begin{array}{c}\text { Correlation } \\
\text { coefficient, } R^{2}\end{array}$ \\
\hline 250 & 1. $\left.\mathrm{min}^{-1}\right)$ & \\
350 & 0.177 & 0.704 \\
\hline
\end{tabular}

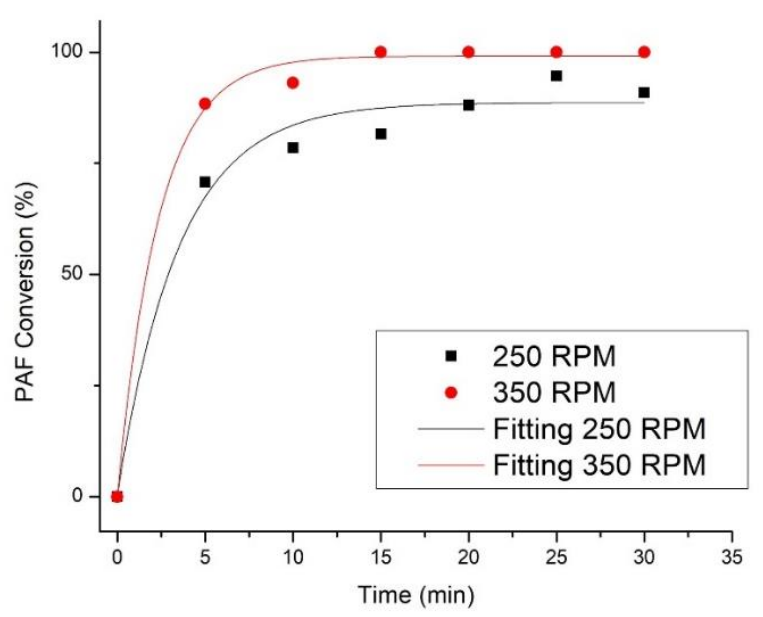

Figure 5. Conversion of PAF with different agitation speed (temperature of $90^{\circ} \mathrm{C}$; PAF to AA mole ratio of $1: 1$ )

The complete process of PAF and AA reaction consisted of two consecutive steps, i.e., PAF dissolution into the water followed by the homogeneous reaction between PAF and
$\mathrm{AA}$ in the aqueous phase. Hence, the kinetic model presented in Eq. (1) assumed a homogeneous reaction. The result in Figure 5 indicated that mixing intensity determined the PAF dissolution degree. At lower mixing intensity, the fine PAF particles might settle at some parts of the reactor and cause lower PAF concentration in the aqueous phase. On the other hand, higher mixing speed led to complete PAF dissolution which then increase the reaction rate. Moreover, as previously mentioned in the earlier discussion about water content by Jiang and $\mathrm{Ni}$ (2018), the solubility of the reactants in this study was still unoptimized due to suboptimal acetic acid to water weight ratio.

In addition, to see whether those operating parameters significantly affected the reaction rate constants, F-test was done with confidence interval value of $95 \%$. From these tests, it was found for all three experiments that the calculated $F$ values were all higher than the F-critical values. Hence, the variation of temperature, reactants' mole ratio, and agitation speed were concluded to have significant effect to the values of the reaction rate constant.

Finally, all the optimum parameters that were concluded in the prior experiments were lumped together and were carried out in one run. Therefore, in the last run, the reaction with PAF to AA mole ratio of $1: 1.5$ was carried out at the temperature of $108{ }^{\circ} \mathrm{C}$ with 350 RPM agitation speed. The conversion of PAF in this run is presented in Figure 6. At these combined optimum conditions, the reaction rate constant value was $1.95 \mathrm{~L} \mathrm{~mol}^{-1} \min ^{-1}\left(R^{2}\right.$ $=0.755)$, which was $37.7 \%$ higher than the highest rate constant obtained at highest temperature but unoptimized reactant mole ratio (Table 1). The complete $100 \%$ conversion 
was also reached in less than 5 minutes. The reaction time was much less than the reaction times in Figure 3, 4, and 5 to reach the $100 \%$ conversion. This finding is very beneficial to improve the profitability of the paracetamol production.

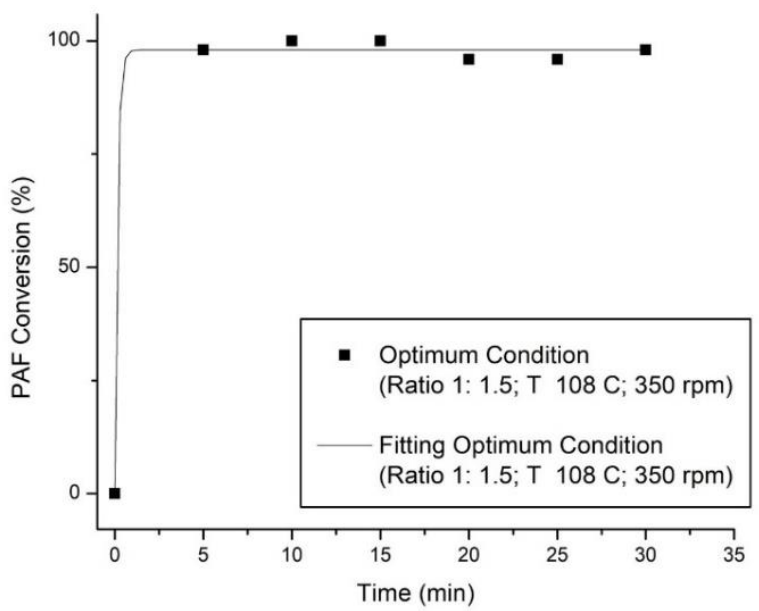

Figure 6. Conversion of PAF with optimum operating condition (temperature of $108^{\circ} \mathrm{C}$; PAF to AA mole ratio of $1: 1.5$; agitation speed of 350 RPM)

\section{Conclusions}

This experiment studied the effect of temperature, para-aminophenol to acetic anhydride mole ratio, and agitation speed to the conversion of para-aminophenol in the production of paracetamol. The optimum temperature, reactant mole ratio, and agitation speed in this study were $108{ }^{\circ} \mathrm{C}$, 1:1.5, and 350 RPM, respectively. The reaction performed under those optimum parameters resulted in the reaction rate constant of 1.95 $\mathrm{L} \mathrm{mol}^{-1} \mathrm{~min}^{-1}$, which was $37.7 \%$ higher that of unoptimized reactant mole ratio. The temperature was the maximum possible temperature for an atmospheric reactor. The agitation speed affected the dissolution rate of PAF in the reaction mixture that indirectly increase the reaction rate. With the aforementioned optimum condition, the complete conversion of PAF has been achieved in less than 5 minutes. By taking into consideration that the reaction time is very short, the recommended condition for the commercial scale production facility in lowering the process temperature to some extent to ensure the safety aspect of the operation. Further experiment is needed to determine the safe limit of the reactors, especially in preventing the chemical losses through vaporization in atmospheric elevated temperature reactor.

\section{Notations}

$r_{P C T}=$ rate of paracetamol generation, mol. $\mathrm{L}^{-1} \cdot \mathrm{min}^{-1}$

$-\frac{d C_{P A F}}{d t}=$ rate of para-aminophenol disappearance, $\mathrm{mol}^{-1} \mathrm{~L}^{-1} \cdot \mathrm{min}^{-1}$

$k=$ second order kinetic rate constant of paracetamol production reaction, L. $\mathrm{mol}^{-1} \cdot \mathrm{min}^{-1}$

$C_{P A F}=$ concentration of paraaminophenol, mol. $\mathrm{L}^{-1}$

$C_{A A}=$ concentration of acetic anhydride, mol. $\mathrm{L}^{-1}$

$E_{a} \quad=$ activation energy of paracetamol production reaction, J. $\mathrm{mol}^{-1}$

$A=$ frequency factor, L. $\mathrm{mol}^{-1} \cdot \mathrm{min}^{-1}$

$R=$ gas constant, $\mathrm{J}_{\mathrm{mol}} \mathrm{m}^{-1} \cdot \mathrm{K}^{-1}$

$T=$ reaction temperature, $\mathrm{K}$

\section{Acknowledgements}

We would like to thank the Ministry of Research and Technology/National Research and Innovation Agency of the Republic of Indonesia for the financial support through the scheme of PTUPT Research Grant 2020 (NOMOR 1864/UN1/DITLIT/DIT-LIT/PT/2020). We would also like to thank the Ministry of Industry for the help in getting some material that was used in this research. 


\section{References}

Abdullaev, M.G., Abdullaeva, Z.S., Klyuev, M. V., Kafarova, S.S. and Gebekova, Z.G., 2014, Kinetics of the production of $p$ acetaminophenol and $p$ hydroxyphenylsalicylamide by reductive acylation of $p$-nitrophenol on palladiumcontaining anionites, Pharm. Chem. J., 47 (11), 610-611.

Amin, M. and Iqbal, M.S., 2015, Solvent Free Synthesis of Acetaminophen, US Patents No. US9006488B1

Bhattacharya, A., Purohit, V.C., Suarez, V., Tichkule, R., Parmer, G. and Rinaldi, F., 2006, One-step reductive amidation of nitro arenes: Application in the synthesis of Acetaminophen $^{\mathrm{TM}}$, Tetrahedron Lett., 47 (11), 1861-1864.

BPS-Statistics Indonesia., 2016, Foreign Trade Statistical Bulletin: Import December 2016. BPS-Statistics Indonesia., 2019, Foreign Trade Statistical Bulletin: Import December 2019. Caldeira, R.L.F. de., 2010, An Assessment of Cross-Contamination Issues in the Context of Chemical and Pharmaceutical Processes Using a Continuous Oscillatory Baffled Reactor, PhD Thesis, Heriot-Watt University, United Kingdom

Du, Y., Chen, H., Chen, R. and Xu, N., 2004, Synthesis of $p$-aminophenol from $p$ nitrophenol over nano-sized nickel catalysts, Appl. Catal. A Gen., 277 (1-2), 259-264.

Jiang, M. and Ni, X.W., 2018, Effects of water and temperature on reaction mechanism and crystal properties in a reactive crystallization of paracetamol, Chem. Eng. Process. - Process Intensif., 131, 20-26.

Jie, D., Yongjun, L. and Jianguo, L., 2003, Process for prepraring $p$ - acetpamidophenol, China patents No CN1434026A.

Jing, Z., 2014, Process for synthesizing paracetamol, China patents No CN105622449A.

Joncour, R., Duguet, N., Métay, E., Ferreira, A. and Lemaire, M., 2014, Amidation of phenol derivatives: A direct synthesis of paracetamol (acetaminophen) from hydroquinone, Green Chem., 16 (6), 29973002.

Kumar, R., Jain, S. and Jain, N., 2013, Synthesis and evaluation of acetaminophen derivatives as analgesic, antipyretic and anti-inflammatory agents, Sch. Res. Libr., 5 (3), 73-78.

Lee, H.L., Lin, H.Y. and Lee, T., 2013, The impact of reaction and crystallization of acetaminophen (Paracetamol) on filtration and drying through in-process controls, Org. Process Res. Dev., 17, 1168-1178.

Mane, S.N., Gadalkar, S.M. and Rathod, V.K., 2018, Intensification of paracetamol (acetaminophen) synthesis from hydroquinone using ultrasound, Ultrason. Sonochem., 49, 106-110.

Min, K. II, Choi, J.S., Chung, Y.M., Ahn, W.S., Ryoo, R. and Lim, P.K., 2008, pAminophenol synthesis in an organic/aqueous system using $\mathrm{Pt}$ supported on mesoporous carbons, Appl. Catal. A Gen., 337 (1), 97-104.

Ministry of Research and Technology of the Republic of Indonesia., 2020, Prioritas Riset Nasional, pp. 1-13.

Pyka, A., Wiatr, E., Kwiska, K. and Gurak, D., 2011, Validation thin layer chromatography for the determination of naproxen in tablets and comparison with a pharmacopeil method, J. Liq. Chromatogr. Relat. Technol., 34 (10-11), 829-847. 
Ralph, J., Karlen, S. and Mobley, J., 2019, Van de Straat, R., De Vries, J., Groot, E.J., Zijl, Synthesis of paracetamol (acetaminophen) R. and Vermeulen, N.P.E., 1987, from biomass-derived $\quad p^{-} \quad$ Paracetamol, 3-monoalkyl- and 3,5-dialkyl hydroxybenzamide, US Patents No derivatives: Comparison of their US10286504B2

Rode, C. V., Vaidya, M.J. and Chaudhari, R. V., hepatotoxicity in mice, Toxicol. Appl. Pharmacol., 89 (2), 183-189. 1999, Synthesis of p-aminophenol by catalytic hydrogenation of nitrobenzene, Org. Process Res. Dev., 3 (6), 465-470.

UNDESA., 2019, World Population Prospects 2019, Dep. Econ. Soc. Aff. World Popul. Prospect. 2019.

Rode, C.V., Vaidya, M.J. and Chaudhari, R.V., 2002, Single step hydrogenation of nitrobenzene to $p$-aminophenol, EU Patents No EP1229018A1

Sawalha, R., 2018, Integrated synthesis and crystallization for the continuous manufacturing of paracetamol, Master Thesis, Graz University of Technology, Austria 